\title{
前言: 化学热力学专刊
}

化学热力学是物理化学和热力学的一个重要分支学科, 其利用热力学原理研究物质体系中的化学现象和规 律, 根据物质体系的宏观可测性质和热力学函数关系判断体系的稳定性、变化方向和变化的程度. 学科交叉发展 对化学热力学不断提出新的、更高的要求, 化学热力学研究目前已涵盖溶液化学热力学、热化学、相平衡、热 分析、统计热力学与分子模拟、生物化学热力学、材料化学热力学、绿色化学热力学、胶体界面化学热力学、 能源化学热力学等方向. 发展化学热力学理论、方法和手段, 解决多年来一直没有解决的重要化学热力学难题, 促进化学热力学与相关学科交叉具有重要的意义, 解决“结构-界面-相互作用-时间的多层次及其相互关系”问题, 为各交叉领域的研究奠定科学基础. 在几代化学热力学人的不解努力下, 现阶段我国已形成了一支具有梯队性、 结构合理的高水平科研队伍, 并取得了系列性的高水平研究成果. 在我国化学热力学与热分析研究已获得阶段性 研究成果的基础上, 化学热力学人将继续立足特色, 发挥优势, 不断探索.

《中国科学: 化学》分别在2010和2014年出版了 “化学热力学”专刊, 为我国化学热力学与热分析及相关研究 领域的发展起到了积极的作用. 为了持续集中展现我国近年来的一些重要成果，以2018年召开的“中国化学会第 十九届全国化学热力学和热分析学术会议”为契机, 《中国科学: 化学》拟再次出版“化学热力学”专刊, 进一步促 进化学热力学与热分析、材料、物理、药学、生物学、医学等多学科领域的交叉与渗透, 推动相关学科领域的 发展.

我们对《中国科学：化学》再次出版“化学热力学”专刊表示衷心的感谢, 特别感谢许军舰博士在策划、约 稿、审稿、编辑加工等过程中付出的大量辛勤劳动. 同时, 对专刊所有论文的作者和审稿人表示诚挚的感谢. 由 于水平和能力所限, 工作中难免有不妥之处, 敬请批评指正.

韩布兴 (中国科学院化学研究所) 陈三平 (西北大学) 房大维 (辽宁大学) 

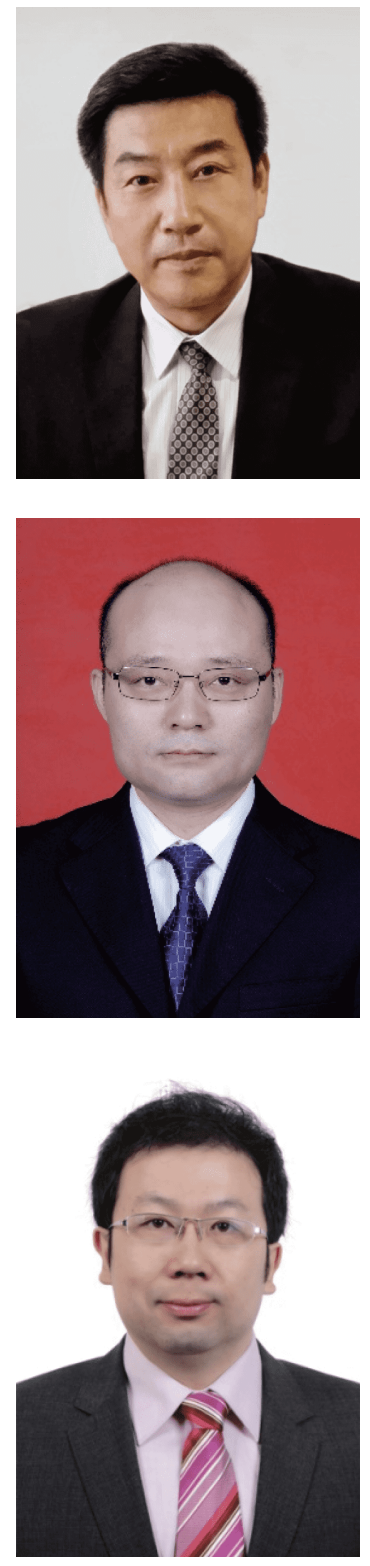

韩布兴, 中国科学院化学研究所研究员、华东师范大学特聘教授、英国诺丁汉 大学荣誉教授, 中国科学院院士、发展中国家科学院院士、英国皇家化学会会 士. 任创新中国智库首席科学家、中国化学会绿色化学专业委员会主任委员、 中国能源科技产业学会副会长; 曾任国际纯粹与应用化学联合会绿色化学分会 主席、中国化学会化学热力学与热分析专业委员会主任委员. 主要从事化学热 力学与绿色化学的交叉研究, 发表SCI收录论文 600 余篇, 获国家发明专利 40 余 件, 获国家和省部级科技奖 5 项, 担任 10 余种期刊的副主编、编委或顾问编委.

陈三平, 教授，博士生导师，陕西省“三五”人才工程第一层次人选，陕西省中青 年科技领军人才. 担任中国化学会化学热力学和热分析专业委员会委员，陕西 省化学会化学热力学专业委员会主任委员. 主持国家级精品资源共享课“无机 化学与化学分析”, 在 《中国大学教学》、《高等理科教育》、 《大学化学》 等期刊发表教学研究论文 30 余篇，合著教材 5 部，获陕西省教学成果奖特等奖 1 项. 从事量热学、分子固体磁化学与物理、含能有机框架材料的化学物理等方 面的研究. 主持国家自然科学基金重大科学仪器研制项目、面上项目，国防预 研项目等．获陕西省科技进步奖二等奖 3 项，发表研究论文 300 余篇. 获陕西省 “师德先进个人”.

房大维, 研究员, 博士生导师, 辽宁省优秀专家, “兴辽英才计划”青年拔尖人才, 辽宁省“百千万人才工程”百人层次. 现任辽宁大学稀散元素研究院院长，辽宁 省稀散元素重点实验室主任, 辽宁省稀散元素资源深加工与应用工程实验室主 任，中国化学会化学热力学和热分析学术委员会副主任委员，中国稀散金属冶 金学术委员会副主任委员，中国有色金属节能减排专业委员会副主任委员. 主 要从事稀散元素功能材料的热力学性质及催化应用研究. 在国内外学术期刊发 表研究论文 100 余篇, 出版专著1部，参编英文专著1部. 主持国家科技支撑计划 子课题2项，国家自然科学基金3项，中国博士后基金1项，省级项目6项，企业横 向课题多项，授权专利17件，完成小试鉴定 2 项．获辽宁省技术发明二等奖1项， 辽宁省自然科学二等奖1项，辽宁省青年科技奖1项，市级科技进步奖 2 项，第十 届辽宁省优秀科技工作者, 沈阳市优秀科技工作者, 沈阳振兴发展带头人. 